\title{
Immunology and Systemic Inflammation Biomarkers Among Saudi Patients with Sickle Cell Anemia in Asymptomatic Steady State Condition
}

\author{
Fadwa M Alsharif* \\ *Department of Medical Laboratory Technology, King Abdulaziz University, Saudi Arabia
}

Submission: May 6, 2017; Published: June 06, 2017

*Corresponding author: Fadwa M Alsharif, Department of Medical Laboratory Technology, Faculty of Applied Medical Sciences, King Abdulaziz University, Saudi Arabia, Email: drfadwa6@gmail.com

\begin{abstract}
Background \& Objective: Sickle cell anemia (SCA) comprises an inherited blood disorder that is lifelong and affects many people globally. Despite progress in therapy, SCA is a considerable cause of mortality and morbidity. This study was designed to measure the immunological parameters and inflammatory cytokines of Saudi patients with sickle cell anemia (SCA) in asymptomatic steady state.

Material and Methods: Fifty asymptomatic sickle cell anemia patients and fifty age- and sex-matched healthy non-sickle cell disease subjects were involved in this study.

Results: The number of white blood cells, neutrophil, lymphocytes, eosinophils, basophils, CD3, CD4 and CD8 count were significantly elevated in stable-state SCA patients when compared with healthy controls. In addition, the mean value of CRP, TNF- $\alpha$, IL-2, IL-4, IL- 6 and IL-8 were significantly elevated in stable-state SCApatients when compared with healthy controls.

Conclusion: High levels of serum cytokines and immune system activation are evident in Saudi SCA patients in asymptomatic steady state.

Keywords: Cytokines; Immune parameters; Sickle cell disease; Stable state
\end{abstract}

\section{Introduction}

Sickle cell anemia (SCA) is a genetic red blood cells (RBCs) disease lead to vaso-occlusion and hemolysis due to abnormal sickle shape and rigid RBCs [1]. Patients with SCA usually suffer from attacks of vaso-occlusive pain, poor quality of life [1,2]. About 275000 individuals suffer of SCA as new cases annually as estimated by WHO [3-5]. Sickle cell anemia (SCA) is an incurable chronic medical problem with homozygous for hemoglobin $\mathrm{S}(\mathrm{HbS}$ ) [6] that induce tissue ischemia and infarction due to vascular occlusion that initiates inflammatory responses $[7,8]$.

Multiple co-morbidities usually associated with SCA as pulmonary hypertension, acute chest syndrome, strokeleg ulcers [9] and spleen infarction especially in subjects living at high altitudes [10]. Cardiac arrest, pulmonary embolism, heart failure, infections, multi-system failure and stroke are the common causes of death among patients with SCA [1113]. Life-threatening infections due to insufficiency of immune system in patients with SCA is common, especially with Streptococcus pneumoniae and Haemophilusinfluenzae [14].
Therefore,Moreover, crisis in SCA is precipitated by infection [15].

This study was designed to measure the immunologic parameters and inflammatory cytokines of Saudi patients with sickle cell anemia (SCA) in asymptomatic steady state.

\section{Subjects and Methods}

\section{Subjects}

Fifty sickle cell anemia Saudi patients in stable state that presented at the Hematology Department, King Abdalaziz University Hospital were randomly recruited into the study from the available patients in the Hematology Department out clinic. Cases were selected from patients whose blood samples were submitted to the hematology section for hemoglobin electrophoresis, which was either advised by their treating doctor or was performed to confirm a positive sickling test. All confirmed patients of sickle cell haemoglobinopathy diagnosed by the presence of Hemoglobin ' $S$ ' band on hemoglobin 


\section{Current Research in Diabetes \& Obesity Journal}

electrophoresis and only homozygous Sickle cell disease patients (patients whose electrophoresis showed presence of Hemoglobin 'S' band with or without Hemoglobin 'F' band - HbSS genotype) were included in the study. Apparently fifty healthy subjects of both gender and age matched subjects were enrolled and considered as control group.Informed consent was signed by all participants. Exclusion criteria included sickle cell disease patient with concurrent HIV or overt infection. Also, SCA patient with painful vaso-occlusive crisis (VOC) with musculoskeletal bone.

\section{Methods}

\section{Evaluated Parameters}

Flow cytometry analysis: The human leukocyte differentiation antigens CD3, CD4 and CD8 (Beckman Coulter, Marseille, France) five microliters of appropriate monoclonal antibody was added to fifty $\mu \mathrm{L}$ of a whole blood sample and incubated for 15 minutes at troom temperature. The samples were analyzed by flow cytometry using Cytomics FC500 and CXP software (Beckman Coulter) [16].

Analysis of peripheral blood cells: A Beckman Coulter AcT 5diff hematology analyzer was used to apply total and differential peripheral blood cells count analysis [16].

Inflammatory cytokine analysis: Serum IL-2, IL-4, IL-6, IL-8, C-reactive protein (CRP) and tumor necrosis factor alpha (TNF- $\alpha$ ) levels were measured with highly sensitive ELISA kits (Quantikine ELISA kits) via R\&D Systems Inc., Minneapolis, MN [17].

Statistical analysis: Independent t-test was used to compare differences between both groups. Statistical analysis of data was performed using SPSS (Chicago, IL, USA) version 17. All data were expressed as the mean $\pm \mathrm{SD}$. $\mathrm{P}<0.05$ indicated statistical significance.

Results

Table 1: Of demographic variables between both groups.

\begin{tabular}{|c|c|c|c|}
\hline & Group (A) & Group (B) & Significance \\
\hline $\begin{array}{l}\text { Age (year) } \\
\text { Comparison }\end{array}$ & $\begin{array}{c}25.16 \pm \\
7.14\end{array}$ & $\begin{array}{c}24.54 \pm \\
7.63\end{array}$ & $\mathrm{P}>0.05$ \\
\hline Weight (kg) & $\begin{array}{c}35.75 \pm \\
11.83\end{array}$ & $\begin{array}{c}29.11 \pm \\
13.72\end{array}$ & $\mathrm{P}>0.05$ \\
\hline Height $(\mathrm{cm})$ & $\begin{array}{c}146.19 \pm \\
16.67\end{array}$ & $\begin{array}{c}143.21 \pm \\
15.84\end{array}$ & $\mathrm{P}>0.05$ \\
\hline $\begin{array}{c}\text { BMI (kg/ } \\
\text { m2) }\end{array}$ & $\begin{array}{c}18.13 \pm \\
4.16\end{array}$ & $\begin{array}{c}16.85 \pm \\
3.98\end{array}$ & $P>0.05$ \\
\hline $\begin{array}{l}\text { Systolic } \\
\text { blood } \\
\text { pressure } \\
(\mathrm{mm} \mathrm{Hg})\end{array}$ & $\begin{array}{c}115.41 \pm \\
11.52\end{array}$ & $\begin{array}{c}116.87 \pm \\
10.31\end{array}$ & $P>0.05$ \\
\hline $\begin{array}{l}\text { Diastolic } \\
\text { blood } \\
\text { pressure } \\
(\mathrm{mm} \mathrm{Hg})\end{array}$ & $\begin{array}{c}76.23 \pm \\
6.64\end{array}$ & $\begin{array}{c}77.15 \pm \\
6.22\end{array}$ & $P>0.05$ \\
\hline
\end{tabular}

BMI: Body Mass Index .
Regarding the demographic variables, both groups were considered homogeneous (Table 1). The mean age of the SCA group was $25.16 \pm 7.14$ years, where the control group was $24.54 \pm 7.63$ years. There were no significant differences in weight, height, body mass index (BMI), systolic blood pressure and diastolic blood pressure between both groups.

The number of white blood cells, neutrophil, lymphocytes, eosinophils, basophils, CD3, CD4 and CD8 count were significantly elevated in stable-state SCA patients when compared with control group (Table 2). In addition, the mean value of CRP, TNF$\alpha$, IL-2, IL-4, IL-6 and IL-8 were significantly elevated in stablestate SCA patients when compared with normal controls (Table 3).

Table 2: Mean value and significance of white blood cells, neutrophil, lymphocytes, eosinophils, basophils, CD3, CD4 and CD8 count of group (A) and group (B).

\begin{tabular}{|c|c|c|}
\hline $\begin{array}{c}\text { White blood cells count } \\
\text { (109/liter) }\end{array}$ & $9.67 \pm 3.83^{*}$ & Group (B) \\
\hline $\begin{array}{c}\text { Neutrophil count (\% of } \\
\text { white blood cells) }\end{array}$ & $55.25 \pm 6.42^{*}$ & $47.31 \pm 3.16$ \\
\hline $\begin{array}{c}\text { Lymphocytes (\% of white } \\
\text { blood cells) }\end{array}$ & $39.12 \pm 13.17^{*}$ & $48.32 \pm 10.87$ \\
\hline $\begin{array}{c}\text { Eosinophils (\% of white } \\
\text { blood cells) }\end{array}$ & $3.63 \pm 2.32^{*}$ & $3.16 \pm 2.15$ \\
\hline $\begin{array}{c}\text { Basophils (\% of white } \\
\text { blood cells) }\end{array}$ & $2.31 \pm 1.17^{*}$ & $2.88 \pm 1.13$ \\
\hline RBC (×1012/liter) & $2.8 \pm 0.5^{*}$ & $4.4 \pm 0.3$ \\
\hline CD3 count(109/L) & $1.82 \pm 0.97^{*}$ & $1.43 \pm 0.87$ \\
\hline CD4 count(109/L) & $1.37 \pm 0.63^{*}$ & $1.08 \pm 0.61$ \\
\hline CD8 count(109/L) & $0.84 \pm 0.32^{*}$ & $0.57 \pm 0.21$ \\
\hline
\end{tabular}

${ }^{*}$ ) indicates a significant difference between the two groups, $\mathrm{P}<0.05$.

Table 3: Mean value and significance of CRP, TNF- $\alpha$, IL-2, IL-4, IL-6 and IL-8 of group (A) and group (B).

\begin{tabular}{|c|c|c|}
\hline & Group (A) & Group (B) \\
\hline CRP $(\mathrm{mg} / \mathrm{dl})$ & $13.24 \pm 3.86^{*}$ & $9.89 \pm 3.17$ \\
\hline TNF- $\alpha(\mathrm{pg} / \mathrm{mL})$ & $5.73 \pm 1.52^{*}$ & $4.16 \pm 1.31$ \\
\hline $\mathrm{IL}-2(\mathrm{pg} / \mathrm{mL})$ & $6.42 \pm 2.35^{*}$ & $4.22 \pm 1.98$ \\
\hline $\mathrm{IL}-4(\mathrm{pg} / \mathrm{mL})$ & $4.53 \pm 1.61^{*}$ & $3.21 \pm 1.42$ \\
\hline $\mathrm{IL}-6(\mathrm{pg} / \mathrm{mL})$ & $6.75 \pm 2.19^{*}$ & $5.18 \pm 1.83$ \\
\hline $\mathrm{IL}-8(\mathrm{pg} / \mathrm{mL})$ & $15.32 \pm 4.25^{*}$ & $11.48 \pm 3.37$ \\
\hline
\end{tabular}

CRP: C - reactive protein ; IL-2 :Interleukin-2; IL-4: Interleukin-4 ; IL-6:Interleukin-6 ; TNF-a: tumor necrosis factor - alpha ; IL-8 : Interleukin-8; $\left(^{*}\right)$ indicates a significant difference between the two groups, $\mathrm{P}<0.05$.

\section{Discussion}

Sickle cell anemia is now the world's most common genetic defects. About $5 \%$ of the population carry a haemoglobinopathy trait worldwide, there are about 300,000 born annually worldwide with hemoglobin disorder [18]. Despite the significant increase in research and number of published articles on SCA and its complications remain elusive [19]. Many authors stated 


\section{Current Research in Diabetes \& Obesity Journal}

that SCA is well recognized as a chronic inflammatory disease [20-22] as C-reactive protein (CRP) and other cytokines are elevated in steady state SCD compared with normal subjects [23]. In addition, researches on animals and human being with SCA proved elevation in inflammatory cytokines [24-28]. However, the results of our study confirm elevation of inflammatory cytokines among SCA patients, our findings agreed with many previous studies.

The possible mechanism that makes inflammatory cytokines increased in patients with SCA which include every short half-life and lies of sickle red cells (RBC) and increased protein synthesis and catabolism $[29,30]$. However, systemic inflammation is induced with chronic hemolysis even among steady state SCA [31], In addition transient vaso-occlusive events and subclinical vascular endothelial injury [32]. Moreover, enhanced adhesiveness of sickle reticulocytes and reversibly sickled erythrocytes to the vascular endothelium play a role in increased level of inflammatory cytokines in patients with SCA $[33,34]$.

Concerning immune system parameters, results of the present study confirms immune system activation among SCA patients, our findings agreed with many previous studies. Buison and colleagues \& Hyacinth and colleagues proved that patients with SCA suffer from malnutrition that adversely affect growth and delay muscloskeletal development [35,36]. However, insufficient performance of immune system, endothelial activation and increased inflammatory cytokines are usually associated with malnutrition [37-41]. While, Duitsand colleagues stated that elevated inflammatory cytokines enhance chemotactic stimuli that result in elevated neutrophil percentages in steady state SCA patients [42].

The present study has points of strengths and limitations. The major strength point is the randomization nature of this study, as subjects were selected randomly out of the available subjects. In the other hand, the small sample size is the limitations in the present study. Finally, the results of the present study concluded that levels of serum cytokines and immune system activation are evident in Saudi SCA patients in asymptomatic steady state. Moreover, more researches are needed to measure the impact of many life style modifications on modulation of inflammatory cytokines and immune system activation in SCA patients.

\section{Conclusion}

Within the limits of the present study, it was concluded that SCA increase the levels of serum cytokines and immune system activation are evident in Saudi SCA patients in asymptomatic steady state.

\section{Acknowledgement}

This project was funded by the Deanship of Scientific Research (DSR), King Abdulaziz University, Jeddah, under grant no. (142-27-D1436). The authors, therefore, acknowledge with thanks DSR technical and financial support.

\section{References}

1. Schnog JB, Duits AJ, Muskiet FA, ten Cate H, Rojer RA, et al. (2004) Sickle cell disease; a general overview. Neth J Med 62(10): 364-374.

2. Claster S, Vichinsky EP (2003) Managing sickle cell disease. BMJ 327(7424): 1151-1155

3. Modell B, Darlison M (2008) Global epidemiology of haemoglobin disorders and derived service indicators. Bull World Health Organ 86(6): 480-487.

4. Weatherall DJ (2010) The inherited diseases of hemoglobin are an emerging global health burden. Blood 115(22): 4331-4336.

5. Modell B, Darlison M (2008) Global epidemiology of haemoglobin disorders and derived service indicators. Bull World Health Organ 86(6): 480-487.

6. Musa BO, Onyemelukwe G, Hambolu J, Mamman A, Isa AH (2010) Pattern of Serum Cytokine Expression and T-Cell Subsets in Sickle Cell Disease Patients in Vaso-Occlusive Crisis. Clin Vaccine Immunol 17(4): 602-608.

7. Ballas SK (1995) The sickle cell painful crisis in adults: phases and objective signs. Hemoglobin 19(6): 323-333.

8. Ballas SK, Mohandas N (1996) Pathophysiology of vaso-occlusion. Hematol Oncol Clin North Am 10: 1221-1239.

9. Lane PA (1996) Sickle cell disease. Pediatrclin N Am 43: 639-664.

10. Tsaras G, Owusu-Ansah A, Boateng FO, Amoateng-Adjepong Y (2009) Complications associated with sickle cell trait: a brief narrative review. AmJ Med 122(6): 507-512.

11. Fitzhugh CD, Lauder N, Jonassaint JC, Telen MJ, Zhao X, et al. (2010) Cardiopulmonary complications leading to premature deaths in adult patients with sickle cell disease. Am J Hematol 85(1): 36-40.

12. Platt OS, Brambilla DJ, Rosse WF, Milner PF, Castro O, et al. (1994) Mortality in sickle cell disease. Life expectancy and risk factors for early death. N Engl J Med 330(23): 1639-1644.

13. Quinn CT, Rogers ZR, Buchanan GR (2004) Survival of children with sickle cell disease. Blood 103(11): 4023-4027.

14. Overturf GD (2003) Prevention of invasive pneumococcal infection in sickle cell disease: on the threshold of a new era of successes? J Pediatr 143(4): 423-425.

15. Booth C, Inusa B, Obaro SK (2010) Infection in sickle cell disease: A review. Int J Infect Dis 14(1): e2-e12.

16. Brown M, Wittwer C (2000) Flow Cytometry: Principles and Clinical Applications in Hematology. Clinical Chemistry August 46(8): 12211229.

17. Kang SY, Kim MH, Lee WI (2010) Measurement of inflammatory cytokines in patients with rheumatoid arthritis. Korean J Lab Med 30(3): 301-306.

18. Cope A, Darbyshire PJ (2013) Sickle cell disease, update on management. Paediatrics and Child Health 11: 480-484.

19. Arteta M, Koumbourlis AC (2014) Controversies in the Diagnosis and Treatment of Sickle Cell Lung Disease. Paediatr Respir Rev 15(1): 3.

20. Belcher JD, Marker PH, Weber JP, Hebbel RP, Vercellotti GM (2000) Activated monocytes in sickle cell disease: potential role in the activation of vascular endothelium and vaso-occlusion. Blood 96(7): 2451-2459. 


\section{Current Research in Diabetes \& Obesity Journal}

21. Belcher JD, Bryant CJ, Nguyen J, Bowlin PR, Kielbik MC, et al. (2003) Transgenic sickle mice have vascular inflammation. Blood 101(10): 3953-3959.

22. Klings ES, Farber HW (2001) Role of free radicals in the pathogenesis of acute chest syndrome in sickle cell disease. Respir Res 2(5): 280285

23. Jison ML, Munson PJ, Barb JJ, Suffredini AF, Talwar S, et al. (2004) Blood mononuclear cell gene expression profiles characterize the oxidant, hemolytic, and inflammatory stress of sickle cell disease. Blood 104(1) 270-280.

24. Hibbert JM, Hsu LL, Bhathena SJ, Irune I, Sarfo B, et al. (2005) Proinflammatory cytokines and the hypermetabolism of children with sickle cell disease. Exp Biol Med (Maywood) 230(1): 68-74.

25. Makis AC, Hatzimichael EC, Mavridis A, Bourantas KL (2000) Alpha2-macroglobulin and interleukin-6 levels in steady-state sickle cell disease patients. Acta Haematol 104(4): 164-168.

26. Barbeau P, Woods KF, Ramsey LT, Litaker MS, Pollock DM, et al. (2001) Exercise in sickle cell anemia: effect on inflammatory and vasoactive mediators. Endothelium 8(2): 147-155.

27. Banerjee T, Kuypers FA (2004) Reactive oxygen species and phosphatidylserine externalization in murine sickle red cells. $\mathrm{Br}$ J Haematol 124(3): 391-402.

28. Hyacinth H , Capers P, Archer D, Hibbert J (2014) TNF- $\alpha$, IFN- $\gamma$, IL10 , and IL-4 levels were elevated in a murine model of human sickle cell anemia maintained on a high protein/ calorie diet. Exp Biol Med (Maywood) 239(1): 65-70.

29. Salman EK, Haymond MW, Bayne E, Sager BK, Wiisanen A, et al. (1996) Protein and energy metabolism in prepubertal children with sickle cell anemia. Pediatr Res 40(1): 34-40.

30. Singhal A, Parker S, Linsell L, Serjeant G (2002) Energy intake and resting metabolic rate in preschool Jamaican children with homozygous sickle cell disease. Am J Clin Nutr 75(6): 1093-1097.

31. Hibbert JM, Hsu LL, Bhathena SJ, Irune I, Sarfo B, et al. (2005) Proinflammatory cytokines and the hypermetabolism of children with sickle cell disease. Exp Biol Med (Maywood) 230(1): 68-74.
32. Kaul DK, Liu XD, Choong S, Belcher JD, Vercellotti GM, et al. (2004) Anti-inflammatory therapy ameliorates leukocyte adhesion and microvascular flow abnormalities in transgenic sickle mice. Am J Physiol Heart Circ Physiol 287(1): H293-301.

33. Munford RS, Pugin H (2001) Normal responses to injury prevent systemic inflammation and can be immunosuppressive. Am J Respir Crit Care Med 163(2): 316-321.

34. Pathare A, Al Kindi S, Alnaqdy A, Daar S, Knox-Macauly H, et al. (2004) Cytokine profile of sickle cell disease in Oman. Am J Hematol 77(4): 323-328.

35. Buison AM, Kawchak DA, Schall J, Ohene-Frempong K, Stallings VA, et al. (2004) Low vitamin D status in children with sickle cell disease. J Pediatr 145(5): 622-627

36. Hyacinth HI, Gee BE, Hibbert JM (2010) The role of nutrition in sickle cell disease. Nutr Metab Insights 3: 57-67.

37. Katona P, Katona-Apte J (2008) The interaction between nutrition and infection. Clin Infect Dis 46(10): 1582-1588.

38. Fujita J, Tsujinaka T, Ebisui C, Yano M, Shiozaki H, et al. (1996) Role of interleukin-6 in skeletal muscle protein breakdown and cathepsin activity in vivo. Eur Surg Res 28(5): 361-366.

39. Miyake K (2003) Innate recognition of lipopolysaccharide by CD14 and toll-like receptor 4-MD-2: unique roles for MD-2. Int Immunopharmacol 3(1): 119-128.

40. Schroder K, Hertzog PJ, Ravasi T, Hume DA (2004) Interferon- $\gamma$ : an overview of signals, mechanisms and functions. J Leukoc Biol 75(2): 163-189.

41. McKellar GE, McCarey DW, Sattar N, McInnes IB (2009) Role for TNF in atherosclerosis? Lessons from autoimmune disease. Nat Rev Cardiol 6(6): 410-417.

42. Duits AJ, Schnog JB, Lard LR, Saleh AW, Rojer RA (1998) Elevated IL-8 levels during sickle cell crisis. Eur J Haematol 61(5): 302-305.
Your next submission with Juniper Publishers will reach you the below assets

- Quality Editorial service

- Swift Peer Review

- Reprints availability

- E-prints Service

- Manuscript Podcast for convenient understanding

- Global attainment for your research

- Manuscript accessibility in different formats

( Pdf, E-pub, Full Text, Audio)

- Unceasing customer service

Track the below URL for one-step submission https://juniperpublishers.com/online-submission.php 